\title{
EDITORIAL
}

\section{Evolution of infrapopliteal artery stenting}

\author{
Evolução dos implantes de stents em artérias infrapoplíteas
}

\begin{abstract}
Nelson Wolosker*
Over the last 20 years, vascular surgeons have witnessed great evolution of the therapy for infrapopliteal artery obstructive disease.

In the 1970s, patients with obstructive disease of tibial arteries did not have any possibilities for revascularization and had to undergo alternative procedures, such as sympathectomy, neurotripsy or even amputation.

In the 1980s, the introduction of distal bypasses revolutionized vascular surgery and a great number of patients were benefited through restoration of the blood flow for treating wound healing and/or critical ischemia. ${ }^{1}$

With the recent advances in image acquisition systems and instruments, endovascular procedures that in the 1980s and 1990s were restricted to the treatment of small segmental lesions of iliac arteries (today classified as TASC A) started to be used in the femoropopliteal segment at the beginning of this new millennium. ${ }^{2}$

The use of short catheters and stents specially designed for coronaries has given rise to encouraging results in treating obstructive lesions of infragenicular arteries, which has stimulated research and development of appropriate equipment for these arteries to replace adapted equipment. The first generation of distal instruments was 5 to $8 \mathrm{~cm}$ angioplasty balloons with

low compliance, over-the-wire system and high resistance for 0.014 guide-wires. Today, balloons of up to 15 $\mathrm{cm}$ in length are available for 0.035 guide-wires which facilitate the procedures and improve the immediate results from angioplasty of the tibial arteries. ${ }^{3}$

Stents have been improved and have been producing even better results, as can be seen in the study by Bosiers et al. ${ }^{4}$ Their paper provides an extensive review of the literature and results of five types of stents. The bare metal stents are bare metal balloon-expandable stents made with Cobalt

Chromium alloy with high radial strength, good fluoroscopic visibility and available in up to $78 \mathrm{~mm}$ lengths. To inhibit the intimal hyperplasia, there were designed passive coated balloon-expandable stents and drugeluting balloon-expandable stents. To avoid stent fractures frequently observed in superficial femoral artery stents, self-expanding nitinol stents were designed. Finally, to avoid permanent presence of an artificial implant, absorbable stents developed in biocompatible materials that completely degrade after some months.

This paper provides an extensive review of the literature and results of these five types of stents. All these options are presented along with the initial results, which are indeed good and stimulating.
\end{abstract}

* Professor associado, Faculdade de Medicina, Universidade de São Paulo (USP), São Paulo, SP. Membro titular, SBACV.

Não foram declarados conflitos de interesse associados à publicação deste editorial. 
Currently, in our group headed by Prof. Pedro PuechLeão, the first-choice therapy for peripheral obstructive lesions is endovascular surgery. The use of stents in tibial arteries is an essential complement for obtaining better rates of limb salvage.

\section{References}

1. Albers M, Romiti M, De Luccia N, Brochado-Neto FC, Nishimoto I, Pereira CA. An updated meta-analysis of infrainguinal arterial reconstruction in patients with end-stage renal disease. J Vasc Surg. 2007;45:536-42.
2. Wolosker N, Nakano L, Anacleto MM, Puech-Leão P. Primary utilization of stents in angioplasty of superficial femoral artery. Vasc Endovascular Surg. 2003;37:271-7.

3. Yoshida RA, Silva CEC, Sobreira ML, Yoshida WB. Angioplastia infrapoplitea: quanto mais arterias tratar melhor? J Vasc Bras. 2008;7:176-182.

4. Bosiers M, Deloose K, Moreialvar R, Verbist J, Peeters P. Current status of infrapopliteal artery stenting in patients with critical limb ischemia. J Vasc Bras. 2008;7:248-255.

\title{
ATENÇÃO
}

\section{Registros de Ensaios Clínicos}

O Jornal Vascular Brasileiro apóia as políticas para registro de ensaios clínicos da Organização Mundial da Saúde (OMS) e do International Committee of Medical Journal Editors (ICNJE, www.icmje.org), reconhecendo a importância dessas iniciativas para o registro e a divulgação internacional de informação sobre estudos clínicos, em acesso aberto. De acordo com essa recomendação, artigos de pesquisas clínicas devem ser registrados em um Registro de Ensaios Clínicos validados pelos critérios estabelecidos pela OMS e ICMJE, cujos endereços estão disponíveis no site do ICMJE:

\author{
www.actr.org.au \\ www.clinicaltrials.gov \\ www.isctn.org \\ www.umin.ac.jp/ctr/index/htm \\ www.trialregister.nl
}

O número de identificação deverá ser registrado ao final do resumo

A partir de 2008, somente serão aceitos para publicação artigos que tenham recebido um número de identificação nesses registros. 